\title{
Cell-surface proteolytic activity of photosynthetic dinoflagellates
}

\author{
Diane K. Stoecker*, Daniel E. Gustafson Jr. \\ University of Maryland Center for Environmental Science, Horn Point Laboratory, PO Box 775, Cambridge, \\ Maryland 21613, USA
}

\begin{abstract}
We used the artificial substrate L-leucine 7-amido-4-methyl-coumarin (Leu-AMC) to measure leucine aminopeptidase (LAP) of dinoflagellates. Axenic cultures of Alexandrium tamarense, Heterocapsa triquetra and Prorocentrum minimum had considerable LAP associated with the cell surface. In non-axenic cultures of Akashiwo sanguinea, Gonyaulax grindleyi, Gyrodinium uncatenum, Karlodinium micrum and P. minimum, 60 to $99 \%$ of the total LAP activity was found in the $>5 \mu \mathrm{m}$ fraction, indicating association with the dinoflagellates rather than with bacteria. At $20^{\circ} \mathrm{C}$, estimated activity ranged from $0.04 \mathrm{pmol} \mathrm{cell}^{-1} \mathrm{~h}^{-1}$ in the smallest species, $K$. micrum, to $2.56 \mathrm{pmol}$ $\mathrm{cell}^{-1} \mathrm{~h}^{-1}$ in the largest species, G. grindleyi. Activity per cell could be predicted from cell size. During a mixed species dinoflagellate bloom in the Choptank River, a tributary of the Chesapeake Bay, total LAP activity was positively correlated with dinoflagellate concentration. In 'red-water' samples, up to $76 \%$ of LAP activity was in the $>2 \mu \mathrm{m}$ fraction. We calculate that in red-water events, dinoflagellates may account for $50 \%$ or more of the in situ LAP activity. Cell-surface proteases may play a role in nutrition of mixotrophic dinoflagellates by providing amino acids for assimilation. Alternatively, released amino acids may be degraded by cell-surface amino acid oxidases to provide ammonium which can be taken up as a source of nitrogen.
\end{abstract}

KEY WORDS: LAP $\cdot$ Ectoenzyme $\cdot$ Mixotrophy $\cdot$ Osmotrophy

Resale or republication not permitted without written consent of the publisher

\section{INTRODUCTION}

Exo- and ecto-enzymes are important in degrading dissolved polymers and particulate organic matter, making monomers available for uptake by planktonic cells. Chróst (1991) has defined extra-cellular or exoenzymes as those that occur free in the water or adsorbed to surfaces other than those of their producers. In contrast, ecto-enzymes are bound to the cell surface or are found in the periplasmic space (Chróst 1991). Leucine aminopepidase (LAP) activity is commonly used as a measure of exo- and ecto-proteolytic activity in the plankton (Rosso \& Azam 1987, Martinez et al. 1996, Crottereau \& Delmas 1998). LAP degrades polypeptides sequentially from the N-terminus. It hydrolyses a broad spectrum of substrates with a free

*Email: stoecker@hpl.umces.edu amino group, but has a preference for N-terminal leucine and related amino acids (Mahler \& Cordes 1966).

LAP and other types of exo- and ecto-proteolytic activity are thought to be primarily due to the activities of heterotrophic bacteria. However, other types of plankton can contribute to activity. For example, heterotrophic flagellates are a source of protease activity (Karner et al. 1994, Sala \& Güde 1999). Martinez \& Azam (1993a) demonstrated that a prokaryotic phytoplankter, Synechococcus, has LAP. However, the contribution of heterotrophic flagellates and cyanobacteria to proteolytic activity in the water column is usually thought to be slight (Martinez \& Azam 1993a, Karner et al. 1994). The contribution of eukaryotic phytoplankton to protease activity has only recently been considered (Sala et al. 2001). Mulholland et al. (2002) found that the 'brown tide' alga Aureococcus anophagefferens has high rates of peptide hydrolysis, 
but information is lacking on the ecto-enzymatic capabilities of most phytoplankters.

Recent studies have shown that many phytoplankters are mixotrophic and can either ingest prey (reviewed in Stoecker 1999) or take up dissolved organic carbon and nitrogen (reviewed in Carlsson \& Granéli 1998). Mixotrophy appears to be particularly common among harmful algal bloom species (Smayda 1997, Stoecker 1999). Phytoplankters may also utilize organic substances in other ways than direct uptake. Amino acid oxidases are associated with the cell surface of some phytoplankers, including dinoflagellates, and are involved in release of ammonium that can be used to meet nitrogen requirements for growth (Palenik \& Morel 1990a,b, Mulholland et al. 1998). Phosphate-limited cells of the dinoflagellate Prorocentrum minimum have a cell-surface alkaline phosphatase that may be important in phosphate acquisition from organic compounds (Dyhrman \& Palenik 1997).

Amino acids and other simple monomers are found at relatively low concentrations in most waters and it has generally been thought that they are at too low a concentration to be a significant source of nutrition to most phytoplankton (Flynn \& Butler 1986, Carlsson \& Granéli 1998). However, combined amino acids occur as part of dissolved polymers, colloids and particles and these may be made available as free amino acids by proteases (Chróst 1991, Long \& Azam 1996, Mannino \& Harvey 2000). It should be advantageous for a cell able to utilize amino acids to breakdown proteins and polypeptides into amino acids at its cell surface.

To explore the possibility that phytoplankton have cell surface proteolytic enzymes, we measured LAP of axenic and non-axenic cultures of dinoflagellates. We did experiments in the laboratory to determine if the observed LAP activity was intracellular, ectocellular or extracellular. In the field, we investigated the partitioning of LAP activity into different size fractions to determine if significant activity was associated with the size fraction containing dinoflagellates.

\section{MATERIALS AND METHODS}

Dinoflagellate cultures. Axenic cultures of Alexandrium tamarense and Heterocapsa triquetra were obtained from the Culture Collection of Marine Phytoplankton (CCMP) at Bigelow Laboratory for Ocean Sciences in West Boothbay Harbor, Maine, USA (Table 1). An axenic culture of Prorocentrum minimum was obtained from Mr. Jason Adolf at Horn Point Laboratory, Maryland, USA. The non-axenic dinoflagellate cultures (Table 1) were isolated from the Chesapeake Bay or its tributaries and maintained in our laboratory. All cultures except for A. tamarense were grown in f/2-Si medium (Andersen et al. 1997). A. tamarense was grown in L1 medium (Andersen et al. 1997). The media for the axenic cultures were prepared with seawater (30 psu); the medium for the nonaxenic cultures was prepared with seawater diluted to 15 psu. Cultures were grown at $20^{\circ} \mathrm{C}$, except for $H$. triquetra which was grown at $15^{\circ} \mathrm{C}$, on a $14: 10 \mathrm{~h}$ light:dark cycle at an irradiance of approximately $50 \mu \mathrm{mol}$ photons $\mathrm{m}^{-2} \mathrm{~s}^{-2}$ for $H$. triquetra and $100 \mu \mathrm{mol}$ photons $\mathrm{m}^{-2} \mathrm{~s}^{-2}$ for all others.

To determine the abundance of dinoflagellates in a sample, $10 \mathrm{ml}$ subsamples were fixed with glutaraldehyde (final conc., $1 \%$ ) and stored in the dark at $4{ }^{\circ} \mathrm{C}$ until analysis. One to $5 \mathrm{ml}$ samples, depending on cell densities, were gently filtered onto $2 \mu \mathrm{m}$ pore size black polycarbonate filters (Osmonics) and slides were prepared for epifluorescence microscopy (Stoecker et al. 1997). Slides were frozen at $-20^{\circ} \mathrm{C}$ until counted using standard techniques (Gifford \& Caron 2000).

Axenic cultures were periodically checked for the presence of bacteria. Two ml sub-samples of the fixed samples were then stained with $5 \mu \mathrm{g} \mathrm{ml}^{-1}$ final conc. DAPI, filtered onto $0.2 \mu \mathrm{m}$ pore size black membrane filters (Osmonics) and examined for the presence of bacteria with epifluorescence microscopy at $1000 \times$ magnification (Nikon Eclipse E800 Microscope; Exciter 330 to 380 nm, Barrier 435 to 485, DM mirror) (Porter \& Feig 1980). To determine mean cell size, aliquots of exponentially growing cultures were sized on a Coulter Multisizer and equivalent spherical diameter (ESD) was determined.

Leucine aminopepidase (LAP) assays. The substrate, L-leucine 7-amido-4-methyl-coumarin (Leu-AMC) (Sarath et al. 1989) (Sigma Chemical), was prepared as a $5 \mathrm{mM}$ stock in distilled water and the stock solution was stored frozen in $1 \mathrm{ml}$ aliquots until use. For assays, $20 \mu \mathrm{l}$ of the substrate stock was added to $1 \mathrm{ml}$ of culture, natural sample, or filtrate in semi-UV cuvettes (Fisherbrand); this resulted in a final substrate concen-

Table 1. Cultures of dinoflagellates used in leucine aminopeptidase (LAP) assays. ESD: equivalent spherical diameter

\begin{tabular}{|lcc|}
\hline Species & Strain & ESD $(\mu \mathrm{m})$ \\
\hline $\begin{array}{l}\text { Akashiwo sanguinea } \\
\text { (formerly Gymnodinium }\end{array}$ & GS-1 & 38.6 \\
$\quad$ sanguineum) & & \\
Alexandrium tamarense & CCMP 1771 & 29.6 \\
Gonyaulax grindleyi & SAV-1 & 40.2 \\
Gyrodinium uncatenum & GU-1 & 34.0 \\
Heterocapsa triquetra & CCMP 449 & 19.3 \\
Karlodinium micrum & GE (CCMP 1974) & 9.9 \\
$\quad$ (formerly Gymno./Gyro. & & \\
galatheanum) & & 12.7 \\
Prorocentrum minimum & PM-1 & \\
\hline
\end{tabular}


tration of $98 \mu \mathrm{M}$ Leu-AMC. Preliminary experiments showed that a substrate concentration of $25 \mu \mathrm{M}$ LeuAMC was saturating with a dense Prorocentrum minimum culture incubated at $20^{\circ} \mathrm{C}$ for $30 \mathrm{~min}$; thus $98 \mu \mathrm{M}$ Leu-AMC should have been more than sufficient for saturation and to obtain the maximum rate $\left(V_{\max }\right)$.

The samples were incubated in the cuvettes in the dark at 15 or $20^{\circ} \mathrm{C}$, as appropriate, for $30 \mathrm{~min}$. At the end of the incubation the reactions were stopped by adding $100 \mu \mathrm{l}$ of $10 \%$ sodium dodecyl (lauryl) sulfate to each vial and either stored frozen $\left(-20^{\circ} \mathrm{C}\right)$ until fluorescence was determined (Crottereau \& Delmas 1998) or readings were made immediately with a Shimadzu Rf5301PC spectrofluorometer (excitation $380 \mathrm{~nm}$ with a $10 \mathrm{~nm}$ slit, emission $440 \mathrm{~nm}$ with a $1.5 \mathrm{~nm}$ slit width). A standard curve was prepared using concentrations of the product, 7-amino-4-methyl-coumarin (AMC) (Sigma Chemical), ranging from 0 to $10 \mu \mathrm{M}$ in sterile seawater media.

Although boiled blanks are commonly used in LAP assays (Rosso \& Azam 1987), we observed that, with estuarine waters, sometimes boiling increased fluorescence in the absence of added substrate. Instead we used 2 other types of controls. The first type was the samples without added substrate, this controlled for natural fluorescence in the sample or culture. The second control was autoclaved media or seawater, as appropriate, to which substrate was added and incubated along with the experimental samples. This controlled for fluorescence due to the substrate or to bacterial contamination of the substrate that could result in formation of product.

For each assay, triplicate cuvettes were used for each experimental treatment. Blanks made with substrate and sterile media or seawater were always higher than the blanks made with unamended samples; therefore, the readings from the former were subtracted from the experimental readings before product concentrations were calculated using a standard curve.

Time course experiments with axenic cultures. Time course experiments were run with axenic cultures (Table 1) to determine if enzyme activity depended on growth phase. Alexandrium tamarense and Prorocentrum minimum were grown at $20^{\circ} \mathrm{C}$, but Heterocapsa triquetra, because of its lower temperature optimum, was grown at $15^{\circ} \mathrm{C}$. At the beginning of the experiment, 12 culture tubes were set up with each species, each tube contained $30 \mathrm{ml}$ of fresh medium and a $10 \mathrm{ml}$ inoculum from an early growth stage culture. The tubes were maintained under the same environmental conditions as the stock cultures. A tube of each species was sampled (and then discarded) on Days 1, 2, 3, 5, 7, 10, 14, 18 and 25. This sampling scheme was designed to avoid accidental bacterial contamination during the experiment.
LAP assays were run in triplicate with unfiltered samples from each tube and with samples gently filtered through a glass fiber filter (Whatman GF/F) to determine if the enzyme activity was physically associated with the cells or present free in the media. Enzyme assays were incubated at the same temperature as used for growth of a species. A $10 \mathrm{ml}$ sample from each tube was fixed with glutaraldehyde and used for cell counts and to check for bacterial contamination.

Experiments to determine if LAP activity was extracellular, intracellular or released by cell damage. If the LAP activity was released into the medium or associated with the cell surface, it would be possible to competitively inhibit release of AMC from Leu-AMC by addition of bovine serum albumin (BSA) (Somville \& Billen 1983, Martinez \& Azam 1993b). A competitive inhibition experiment with BSA was done using an axenic culture of Prorocentrum minimum. AMC release from Leu-AMC in the presence of 10.0, 8.6, 6.7, $4.0,1.8$, and $0 \mathrm{mg} \mathrm{BSA} \mathrm{ml}^{-1}$ was compared. Assay procedures were similar to those described in the experimental methods above, except that 0 to $1.0 \mathrm{ml}$ of BSA stock solution $\left(20 \mathrm{mg} \mathrm{ml}^{-1}\right)$ was added to $1 \mathrm{ml}$ of culture in a cuvette. Addition of Leu-AMC stock was adjusted to keep the concentration of substrate constant at $50 \mu \mathrm{M}$.

To test if exposure to the substrate causes the dinoflagellates to lyse, releasing intracellular enzymes, samples of Prorocentrum minimum were fixed with glutaraldehyde before and after 30 min exposure to $50 \mu \mathrm{M}$ Leu-AMC. Slides were prepared and counted so that dinoflagellate cell numbers could be compared. In addition, live samples were examined under a dissecting microscope after exposure to see if the cells were still motile.

To determine if cell lysis would increase LAP activity, due to the release of intracellular enzymes, activity was compared before and after rupturing axenic Prorocentrum minimum cells by freezing and thawing $4 \times$. Three $1 \mathrm{ml}$ aliquots were assayed for LAP before and after treatment.

Experiments with non-axenic dinoflagellate cultures. Late exponential growth phase non-axenic cultures of dinoflagellates were assayed for LAP activity (Table 1). LAP assays were run in triplicate with unfiltered samples of each culture and with samples of each culture that had been gently filtered through a $5 \mu \mathrm{m}$ pore size polycarbonate filter. This porosity was used so that the dinoflagellate cells would be retained but bacteria, including small bacterial aggregates, would be in the filtrate. Incubations were at $20^{\circ} \mathrm{C}$ in the dark for $30 \mathrm{~min}$. Samples of the cultures were fixed and dinoflagellates counted microscopically as previously described. 
Table 2. LAP activity of axenic cultures of Prorocentrum minimum, $20^{\circ} \mathrm{C}$. AMC: 7-amido-4-methyl-coumarin

\begin{tabular}{|c|c|c|c|c|}
\hline Expt & $\begin{array}{l}\text { Concentration } \\
\left(\text { cells } \times 10^{3} \mathrm{ml}^{-1}\right)\end{array}$ & $\begin{array}{c}\mu \text { mol AMC } \\
\text { Total }\end{array}$ & $\begin{array}{l}\text { LAP activity } \\
\left.{ }^{-1} \text { [mean (SD) }\right] \\
\text { GF/F filtrate }\end{array}$ & pmol AMC cell ${ }^{-1} \mathrm{~h}^{-1}$ \\
\hline 1 & 87.0 & $4.92(0.117)$ & $0.02(0.016)$ & 0.06 \\
\hline 2 & 68.9 & $3.34(0.340)$ & $0.00(0.002)$ & 0.05 \\
\hline 3 & 50.0 & $2.76(0.302)$ & $0.04(0.002)$ & 0.06 \\
\hline 4 & 80.5 & $3.52(2.043)$ & $0.00(0.028)$ & 0.04 \\
\hline 5 & 118.1 & $5.22(0.244)$ & $0.00(0.030)$ & 0.04 \\
\hline
\end{tabular}

dicates that the activity is at the cell surface, rather than intracellular.

Time course experiments were done with axenic cultures of Alexandrium tamarense, Heterocapsa triquetra and Prorocentrum minimum to determine if LAP occurred in exponential and stationary phase cultures. Microscopic examination of fixed samples for the presence of bacteria revealed that although cultures of the first 2 species were axenic, the $P$. minimum culture in this experiment was not. LAP activity

Dinoflagellate densities and in situ LAP activity. Samples were taken inside and outside patches of red water in the Choptank River, a tributary of the Chesapeake Bay, on June 27 and 29, 2001. In situ temperature and salinity were measured with a portable YSI SCT meter. Surface water samples were collected and stored in a cooler for transport to the Horn Point Laboratory, where within $2 \mathrm{~h}$ of collection the sample from each station was gently filtered through a Nitex mesh to obtain the $<200 \mu \mathrm{m}$ fraction (containing phytoplankton, microzooplankton and bacteria) and another subsample was gently filtered through a $2 \mu \mathrm{m}$ polycarbonate filter to obtain a $<2 \mu \mathrm{m}$ fraction (containing bacteria). Triplicate subsamples were assayed for LAP as previously described except that the incubation was at $24^{\circ} \mathrm{C}$. To estimate the activity due to dinoflagellates and other protists, the activity in the $<2 \mu \mathrm{m}$ fraction (bacteria size fraction) was subtracted from the activity in the $<200 \mu \mathrm{m}$ fraction. Samples were also fixed in glutaraldehyde (final conc., 1\%) for later microscopic examination.

\section{RESULTS}

\section{Laboratory experiments}

LAP activity was found in axenic cultures of Prorocentrum minimum, with an average production of 0.05 pmol AMC cell ${ }^{-1} \mathrm{~h}^{-1}$ at $20^{\circ} \mathrm{C}$ (Table 2). Less than $1 \%$ of the activity was free in the medium (Table 2 ), indicating that LAP was physically associated with the dinoflagellate cells. $P$. minimum cultures were examined microscopically after exposure to the substrate, which might have caused release of intracellular proteases. After exposure, the dinoflagellates were intact and motile and no damage to the cells was evident. Lysis of the cells by freezing and thawing dramatically reduced LAP activity, indicating that activity was not an artifact due to cell damage but rather that cell damage decreased LAP activity. The protein BSA competitively inhibited LAP activity in P. minimum (Fig. 1), which in- was present in early stationary phase as well as growing cultures (Fig. 2). With A. tamarense, 4 to $30 \%$ of the activity was present in the culture filtrate, but with the other 2 species activity in the filtrate was $<1 \%$ (Fig. 2). LAP was highly correlated with cell number (Fig. 3). Based on the regression of activity against cell density, the mean activity of $A$. tamarense at $20^{\circ} \mathrm{C}$ was $0.72 \mathrm{pmol}$ AMC cell ${ }^{-1} \mathrm{~h}^{-1}$. The mean LAP of $H$. triquetra at $15^{\circ} \mathrm{C}$ was $0.20 \mathrm{pmol} \mathrm{AMC} \mathrm{cell}{ }^{-1} \mathrm{~h}^{-1}$. The mean activity for the non-axenic $P$. minimum at $20^{\circ} \mathrm{C}$ was 0.07 pmol AMC cell ${ }^{-1} \mathrm{~h}^{-1}$.

With non-axenic cultures of dinoflagellates, $63 \%$ or more of the total LAP activity was in the $>5 \mu \mathrm{m}$ fraction (Table 3), which contained mostly dinoflagellates rather than free-living bacteria. Dinoflagellate-specific LAP was estimated from the activity in the $>5 \mu \mathrm{m}$ fraction and ranged from 0.04 pmol AMC cell ${ }^{-1} \mathrm{~h}^{-1}$ in the smallest species, Karlodinium micrum, to $2.56 \mathrm{pmol}$ AMC cell ${ }^{-1} \mathrm{~h}^{-1}$ in the largest species, Gonyaulax grindleyi (Table 3).

Data from incubations with both axenic and nonaxenic cultures were used to determine if cell-specific LAP activity could be predicted from cell size. The rate

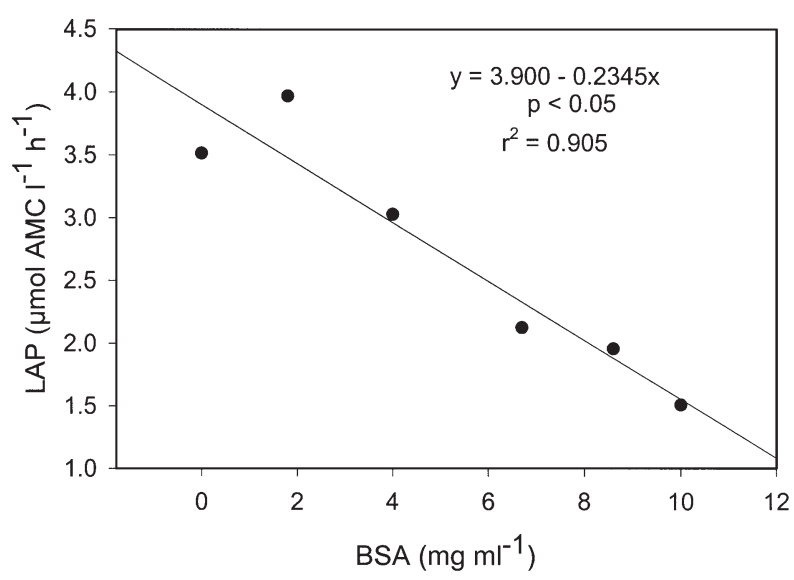

Fig. 1. Inhibition of leucine aminopeptidase (LAP) activity of axenic Prorocentrum minimum by addition of bovine serum albumin (BSA). AMC: 7-amido-4-methyl-coumarin 
for Heterocapsa triquerta at $15^{\circ} \mathrm{C}$ was corrected to $20^{\circ} \mathrm{C}$ for comparison with the other species using a $Q_{10}$ of 2.5 for protists (Caron et al. 1990). LAP activity per cell was predictable from cell volume (Fig. 4).

\section{Association of LAP with a dinoflagellate bloom in the Choptank River}

A patchy dinoflagellate bloom occurred in the Choptank River, a tributary of the Chesapeake Bay, in late June 2001. Photosynthetic dinoflagellate densities reached over 2000 cells $\mathrm{ml}^{-1}$ in patches of red water (Table 4). The bloom consisted of a mixture of Gyrodinium/Gymnodinium spp., Prorocentrum minimum, and Karlodinium micrum. In situ LAP activity in surface waters ranged from 0.44 to $2.34 \mu \mathrm{mol} \mathrm{AMC} \mathrm{l}^{-1} \mathrm{~h}^{-1}$, with 8 to $76 \%$ of the activity associated with the 2 to $200 \mu \mathrm{m}$ fraction, which is the size range containing dinoflagellates as well as other protists (Table 4). LAP activity in the $<200 \mu \mathrm{m}$ fraction was positively correlated with density of photosynthetic dinoflagellates, but activity in the $<2 \mu \mathrm{m}$ fraction was not significantly correlated with density of dinoflagellates (Fig. 5). LAP activity in the $<200 \mu \mathrm{m}$ fraction could be best predicted from a combination of dinoflagellate number and salinity, with higher activities associated with lower salinity (Table 5).

\section{DISCUSSION}

Ecto-proteolytic activity in seawater is thought to be primarily due to heterotrophic bacteria (Rego et al. 1985, Rosso \& Azam 1987). Chroococcoid cyanobacteria (Martinez \& Azam 1993a) and heterotrophic nanoflagellates (Karner et al. 1994, Sala \& Güde 1999) have extra- or ecto-cellular aminopeptidase and they contribute to proteolytic activity in aquatic environments, but their contribution to bulk activity in the water column is thought to be minor compared to the contribution of heterotrophic bacteria.

Our results indicate that photosynthetic dinoflagellates can contribute significantly to LAP (Fig. 5). At
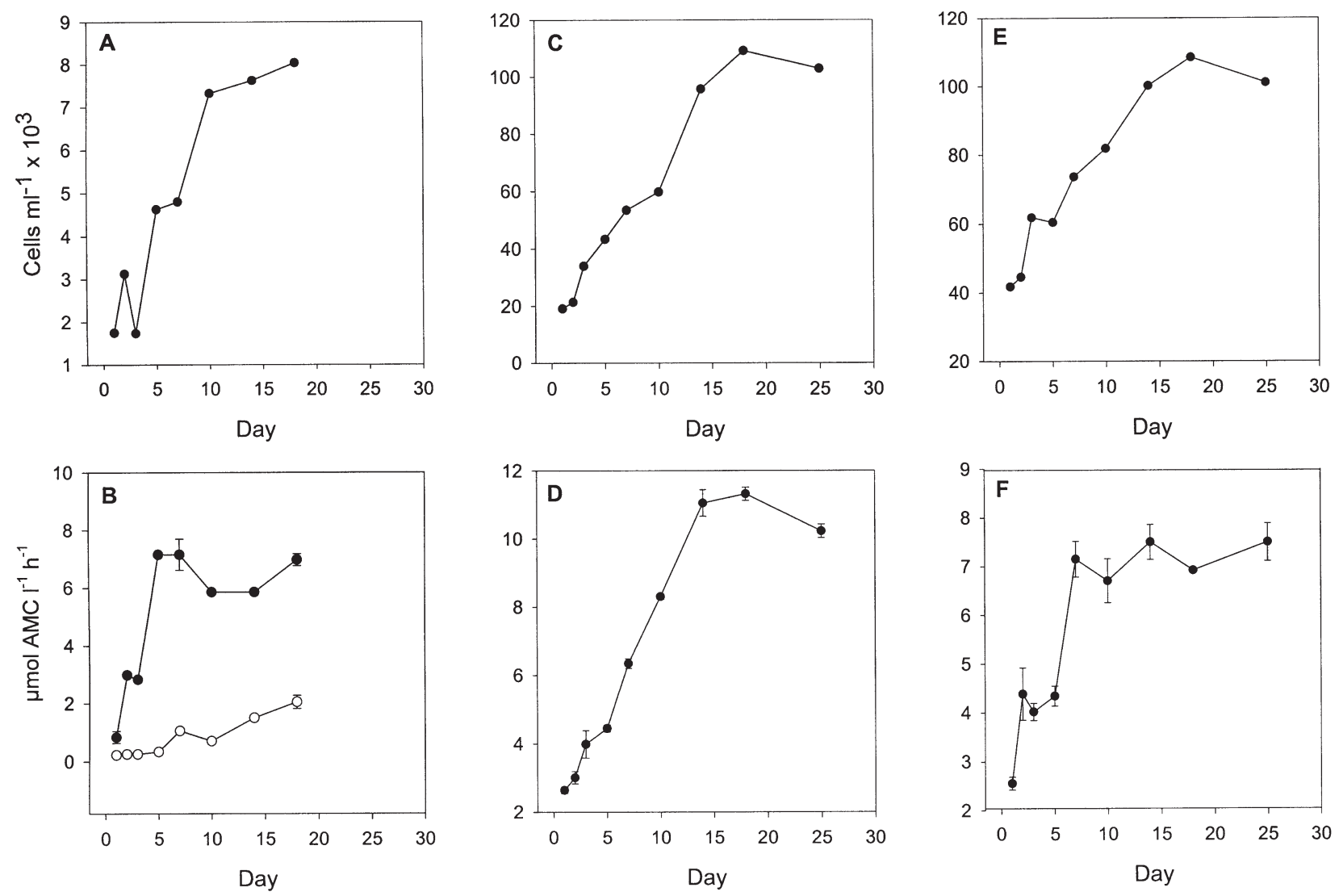

Fig. 2. $(\mathrm{A}, \mathrm{C}, \mathrm{E})$ Growth and $(\mathrm{B}, \mathrm{D}, \mathrm{F})$ increase in LAP activity in axenic cultures of $(\mathrm{A}, \mathrm{B})$ Alexandrium tamarense and $(\mathrm{C}, \mathrm{D})$ Heterocapsa triquetra and in a non-axenic culture of $(\mathrm{E}, \mathrm{F})$ Prorocentrum minimum. $(\mathrm{B}, \mathrm{D}, \mathrm{F})$ Filled circles $=$ total LAP; open circles $=$ LAP in filtrate. With $H$. triquetra and $P$. minimum,$<1 \%$ of the LAP activity was in the filtrate (data not shown for filtrate). Mean \pm standard deviation for LAP activity 

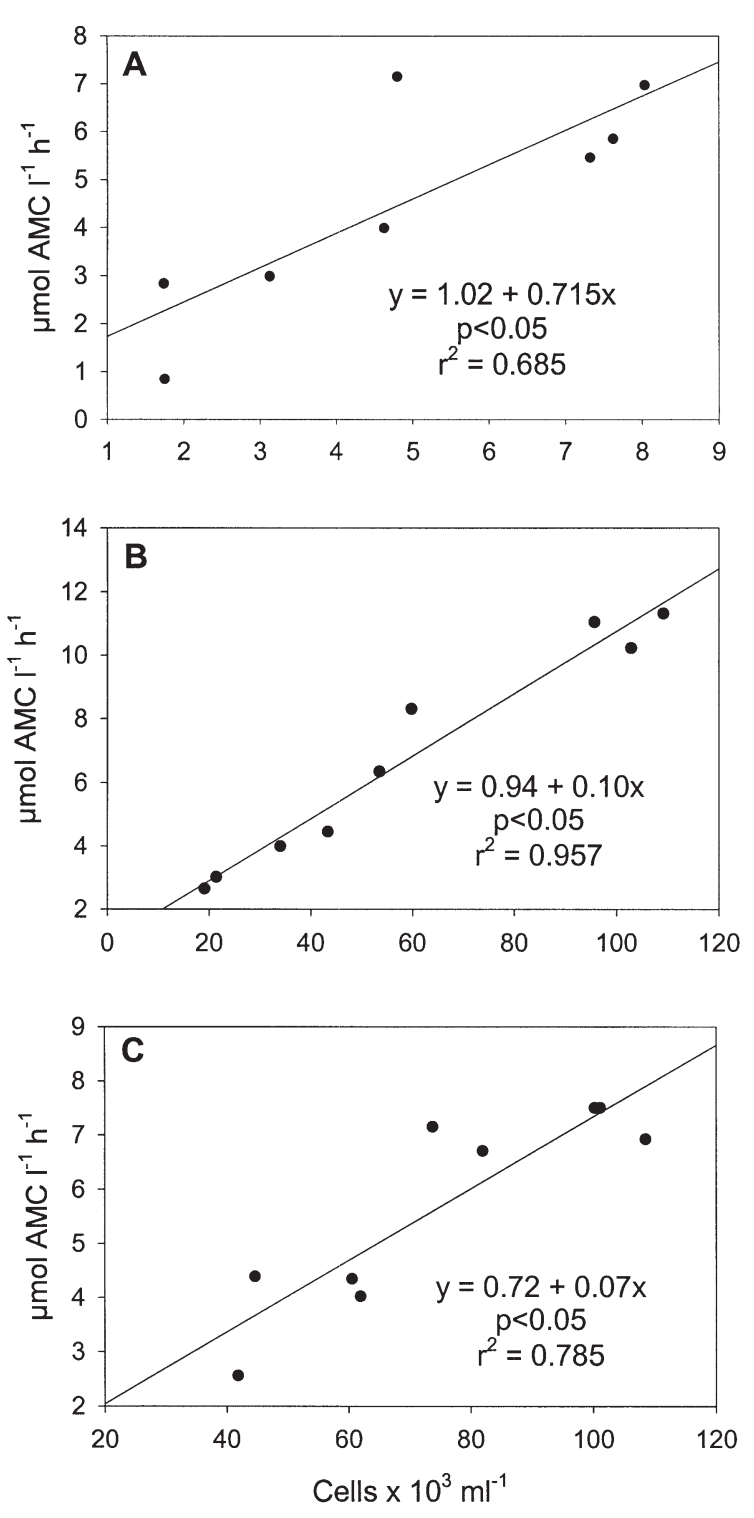

Fig. 3. LAP activity as a function of dinoflagellate cell density. (A) Axenic Alexandrium tamarense, SE of estimate $=1.348$, SE of constant $=1.078$, SE of $x$ coefficient $=0.198$. (B) Axenic Heterocapsa triquetra, SE of estimate $=0.778$, SE of constant $=0.539$, SE of $x$ coefficient $=0.008$. (C) Non-axenic Prorocentrum minimum, $\mathrm{SE}$ of estimate $=0.924, \mathrm{SE}$ of constant $=1.026$, SE of $x$ coefficient $=0.013$

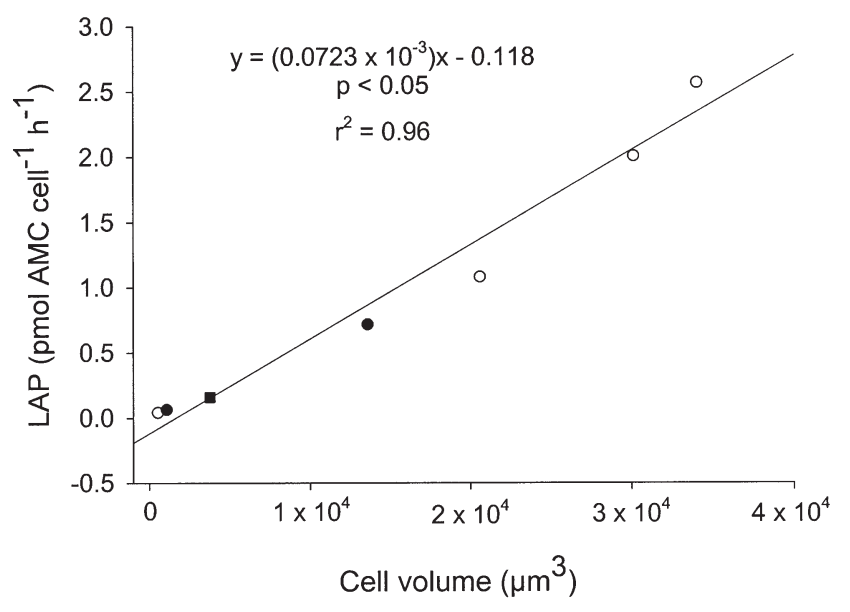

Fig. 4. Cell-specific LAP activity of cultured dinoflagellates at $20^{\circ} \mathrm{C}$ as a function of cell biovolume. Filled symbols $=$ axenic cultures; open symbols $=$ non-axenic cultures. Circles $=$ experiments conducted at $20^{\circ} \mathrm{C}$, square $=$ experiment conducted at $15^{\circ} \mathrm{C}$, data corrected to $20^{\circ} \mathrm{C}$

non-bloom densities, the contribution of dinoflagellates to bulk activity is probably minor, but at bloom densities dinoflagellates may make an important contribution. For example, Prorocentrum minumum peak densities of $10^{4}$ cells $\mathrm{ml}^{-1}$ are reported from the Chesapeake Bay in late spring and early summer (Tyler \& Seliger 1978). With an average maximum LAP activity equivalent to 0.05 pmol AMC cell ${ }^{-1} \mathrm{~h}^{-1}$ (Table 2), $P$. minimum could be responsible for activ-

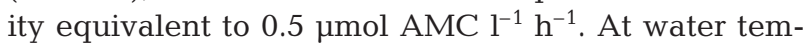
peratures of around $20^{\circ} \mathrm{C}$ during early October 2001, we measured bulk LAP ranging from 0.4 to $1.2 \mu \mathrm{mol}$ AMC $\mathrm{l}^{-1} \mathrm{~h}^{-1}$ in lower and mid Chesapeake Bay (Stoecker unpubl. data). Thus, dense P. minimum blooms in the main stem Bay could have a considerable impact on LAP activity. During red-water conditions in tributaries such as the Choptank River, $P$. minimum densities $>10^{5}$ cells $\mathrm{ml}^{-1}$ are reported (www.dnr.state.md.us/bay). At these extremely high densities, $P$. minimum could contribute LAP activity equivalent to $5.0 \mu \mathrm{mol} \mathrm{AMC} \mathrm{l}^{-1} \mathrm{~h}^{-1}$, about an order of magnitude higher than expected for 'bacterial' LAP in

Table 3. LAP activity of non-axenic dinoflagellate cultures, $20^{\circ} \mathrm{C}$

\begin{tabular}{|c|c|c|c|c|c|}
\hline \multirow{3}{*}{ Species } & \multirow{3}{*}{$\begin{array}{l}\text { Concentration } \\
\left(\text { cells } \times 10^{3} \mathrm{ml}^{-1}\right)\end{array}$} & \multicolumn{4}{|c|}{$\longrightarrow$ LAP activity } \\
\hline & & \multicolumn{2}{|c|}{$\mu \mathrm{mol} \mathrm{AMC} \mathrm{l}^{-1} \mathrm{~h}^{-1}$ [mean (SD)] } & \multirow[t]{2}{*}{$\%>5 \mu \mathrm{m}$} & \multirow[t]{2}{*}{ pmol AMC cell ${ }^{-1} \mathrm{~h}^{-1}$} \\
\hline & & Total & $<5 \mu \mathrm{m}$ & & \\
\hline Akashiwo sanguinea & 4.2 & $12.8(0.30)$ & $4.3(0.20)$ & 66 & 2.02 \\
\hline Gonyaulax grindleyi & 3.2 & $12.5(0.48)$ & $4.3(0.08)$ & 66 & 2.56 \\
\hline Gyrodinium uncatenum & 5.5 & $7.8(0.19)$ & $1.8(0.06)$ & 77 & 1.09 \\
\hline Karlodinium micrum & 274.5 & $18.0(0.15)$ & $6.6(0.15)$ & 63 & 0.04 \\
\hline
\end{tabular}


Table 4. Dinoflagellate abundance, environmental parameters and LAP activity, Choptank River, June 2001

\begin{tabular}{|c|c|c|c|c|c|c|c|}
\hline \multirow[t]{2}{*}{ Stn } & \multirow[t]{2}{*}{ Latitude } & \multirow[t]{2}{*}{ Longitude } & \multirow{2}{*}{$\begin{array}{c}\text { Water } \\
\text { Temp. }\left({ }^{\circ} \mathrm{C}\right)\end{array}$} & \multirow[t]{2}{*}{ Salinity } & \multirow{2}{*}{$\begin{array}{l}\text { Dinoflagellates } \\
\quad\left(\text { cells ml }{ }^{-1}\right)\end{array}$} & \multicolumn{2}{|c|}{$\longrightarrow$ LAP activity } \\
\hline & & & & & & $\begin{array}{c}\mu \mathrm{mol} \text { AMC } \mathrm{l}^{-1} \mathrm{~h}^{-1} \\
<200 \mu \mathrm{m}[\text { mean }(\mathrm{SD})]\end{array}$ & $\%>2 \mu \mathrm{m}$ \\
\hline \multicolumn{8}{|c|}{27 June } \\
\hline 1 & $38^{\circ} 36.03$ & $75^{\circ} 59.34$ & 29.1 & 6.0 & 181 & $0.75(0.012)$ & 49 \\
\hline 2 & $38^{\circ} 35.49$ & $76^{\circ} 00.18$ & 27.9 & 6.9 & 304 & $0.96(0.072)$ & 30 \\
\hline 3 & $38^{\circ} 35.38$ & $76^{\circ} 00.50$ & 28.9 & 6.8 & 2046 & $2.18(0.100)$ & 76 \\
\hline 4 & $38^{\circ} 34.72$ & $76^{\circ} 01.12$ & 28.3 & 7.0 & 225 & $1.14(0.024)$ & 45 \\
\hline 5 & $38^{\circ} 34.46$ & $76^{\circ} 01.94$ & 27.7 & 7.6 & 2519 & $1.82(0.031)$ & 42 \\
\hline \multicolumn{8}{|c|}{29 June } \\
\hline $6^{\mathrm{a}}$ & $38^{\circ} 36.35$ & $75^{\circ} 56.25$ & 28.8 & 3.1 & 1170 & $2.34(1.092)$ & 53 \\
\hline 7 & $38^{\circ} 35.07$ & $76^{\circ} 03.90$ & 28.0 & 8.0 & 986 & $1.12(0.188)$ & 8 \\
\hline 8 & $38^{\circ} 35.70$ & $76^{\circ} 07.31$ & 28.0 & 9.2 & 840 & $0.60(0.011)$ & 31 \\
\hline 9 & $38^{\circ} 38.10$ & $76^{\circ} 09.53$ & 28.0 & 11.1 & 189 & $0.44(0.026)$ & 24 \\
\hline
\end{tabular}

temperate coastal and estuarine waters (Martinez \& Azam 1993a, Crottereau \& Delmas 1998). During dense blooms, dinoflagellates are expected to elevate LAP in the nano- and microplankton size fractions, resulting in an increase in total activity. This should result in the increased degradation of proteins and polypeptides in the water column during dinoflagellate blooms.

In the Choptank River in June 2001, LAP activity in 'red water' with $\sim 2 \times 10^{3}$ photosynthetic dinoflagellate cells $\mathrm{ml}^{-1}$ was elevated by 1 to $2 \mu \mathrm{mol} \mathrm{AMC} \mathrm{l}^{-1} \mathrm{~h}^{-1}$ over LAP in samples with a low density of dinoflagellates (Table 4). Assuming an average activity of $0.5 \mathrm{pmol}$ cell $^{-1} \mathrm{~h}^{-1}$ for a small to mid-sized dinoflagellate (see

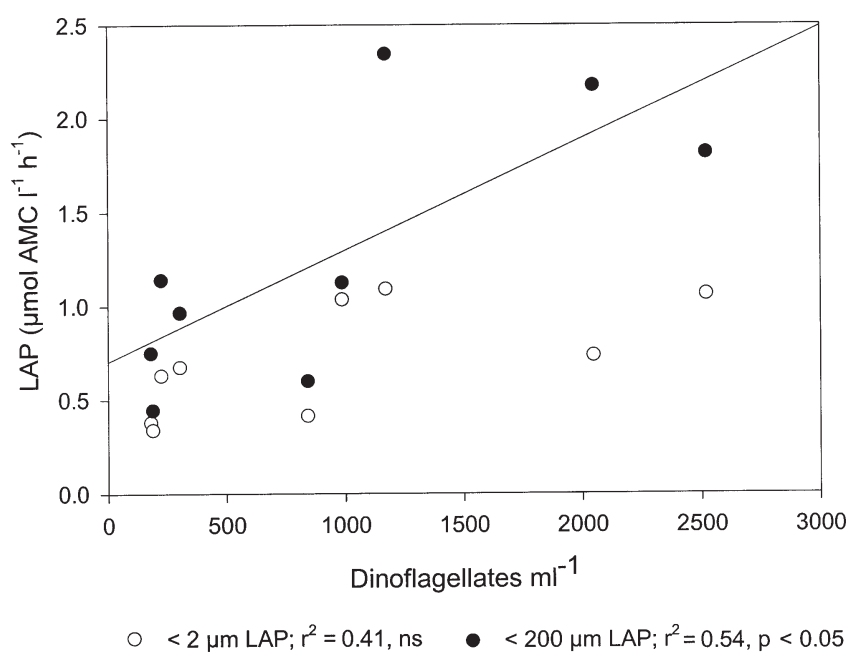

Fig. 5. LAP activity in the Choptank River during a mixed dinoflagellate bloom, June 2001. LAP in the $<2 \mu \mathrm{m}$ fraction (open circles) was not significantly associated with dinoflagellate abundance $\left(r^{2}=0.41, \mathrm{~ns}\right)$. LAP in the $<200 \mu \mathrm{m}$ fraction (filled circles) was positively associated with dinoflagellate abundance $\left(r^{2}=0.54, p<0.05\right)$ data in Fig. 4), LAP activity of $1 \mu \mathrm{mol} \mathrm{AMC} \mathrm{l}^{-1} \mathrm{~h}^{-1}$ is predicted from cell number, which is within the range observed.

Cell-associated LAP with peak activity between $\mathrm{pH}$ 7.5 and 8.5 (the $\mathrm{pH}$ range of seawater) has been reported in homogenates of non-dinoflagellate marine phytoplankton (Berges \& Falkowski 1996). Caseinolytic activity was also measured in the homogenates at $\mathrm{pH}>8$, suggesting that phytoplankton have a diversity of proteases active within the $\mathrm{pH}$ range of seawater. Berges \& Falkowski (1998) found that in some phytoplankton protease activity is related to physiological stress and cell death. It is not known if any of the protease activity detected in the homogenates by Berges \& Falkowski (1996) was associated with the cell surface. We found ecto-cellular LAP activity in cultures grown in inorganic nutrient-rich medium (Figs. 2 \& 3); this suggests that the cell-surface enzymes are constitutive. However, we do not know if nutrient stress would have increased activity. In the plankton, relatively high LAP activity is often associated with low ratios of $N: P$, suggesting that the enzyme may be partially inducible (Sala et al. 2001). However, changes in LAP activity in natural assemblages may be due to changes in species composition or activity, rather than to induction or suppression of LAP in a species.

Table 5. Prediction of in situ LAP activity $(<200 \mu$ m fraction $)$ from abundance of photosynthetic dinoflagellates (DINO) and salinity (PSU). Data from Table 4 . LAP $=2.132+(0.0005 \times$ DINO) $-(0.186 \times$ PSU $)$

\begin{tabular}{|lcccr|}
\hline ANOVA & df & MS & $F$ & $p$ \\
\hline Regression & 2 & 1.685 & 22.556 & 0.002 \\
Residual & 6 & 0.075 & & \\
Total & 8 & & & \\
Adjusted $\mathrm{R}^{2}=0.842$ & & & \\
\hline
\end{tabular}


In contrast to our findings, Carlsson et al. (1998) detected no significant LAP activity in an axenic culture of the dinoflagellate Alexandrium catenella. We do not know why their results were so different to ours. Enzyme activity is often very sensitive to physiochemical conditions and so perhaps differences in water chemistry or preparation of the medium affected results. It is also possible that $A$. catenella just lacks enzyme activity found in the species that we tested.

Ecto-enzyme activity in dinoflagellates may have several functions. Most photosynthetic dinoflagellates are mixotrophic and can supplement their nutrition by ingesting material or taking up dissolved organic matter (reviewed in Carlsson \& Granéli 1998, Stoecker 1999). Dinoflagellates can assimilate dissolved free amino acids but the ecological significance of this uptake is debated (reviewed in Carlsson \& Granéli 1998). Low molecular weight compounds (e.g. amino acids) are assimilated by phytoplankton more readily than macromolecules (e.g. proteins and polypeptides), although there is evidence that dinoflagellates can take up macromolecules by pinocytosis (Carlsson \& Granéli 1998, Carlsson et al. 1998,). Amino acids can provide an additional source of carbon and nitrogen for phytoplankton but, under most conditions in open waters, the environmental concentrations of free amino acids are thought to be too low to support much uptake or growth (reviewed in Flynn \& Butler 1986, John \& Flynn 1999). However, combined amino acids are concentrated in some dissolved polymers, colloids and in particulate organic matter in water (Long \& Azam 1996, Mannino \& Harvey 2000). Release of amino acids from proteins and polypeptides at the dinoflagellate cell surface by ecto-enzymes could supplement the carbon and nitrogen nutrition of photosynthetic dinoflagellates.

It is interesting that in situ LAP activity was inversely related to salinity (Table 5). If dinoflagellate cell size was negatively correlated with salinity in our samples, this could be responsible for the negative correlation of LAP with salinity. However, we have no estimates of average cell size. It is also possible that a difference in dinoflagellate physiology with salinity was responsible. In the Chesapeake Bay, carbon fixation can be limited by inorganic carbon during blooms, particularly at low salinity (Loftus et al. 1979). Uptake of organic carbon should be particularly advantageous under these conditions. We do not know if inorganic carbon limitation of photosynthesis enhances LAP activity in dinoflagellates.

Amino acids can also be used as a source of nitrogen by phytoplankton without direct assimilation. Amino acid oxidases on the surface of phytoplankters can degrade amino acids, releasing ammonium, which is readily assimilated (Palenik \& Morel 1990a). Amino acid oxidases have been found in dinoflagellates (Palenik \& Morel 1990b). By releasing amino acids at the cell surface, ecto-proteolytic enzymes, such as LAP, might facilitate uptake of nitrogen by providing substrate for amino acid oxidases. Information is needed to evaluate the importance of cell-surface proteolytic activity in dinoflagellates and its possible roles in carbon and nitrogen acquisition.

Acknowledgements. This research was supported by NSF grant OCE-981970 to D.K.S. Initial research was conducted with funding from Sea Grant R/P-125-PD to D.K.S. and Dr. Daniel Terlizzi. We thank Ms. Kristi Stevens for help with the preliminary experiments, Mr. Jeffrey Alexander and Mr. Vincent Kelly for collecting samples from the Choptank River, Ms. Jennifer Wolny for identifying Gonyaulax grindleyi, and Ms. Laurie Van Heukelem and Ms. Lois Lane for help with fluorometry. Insights and suggestions of Dr. Hugh MacIntyre improved an early draft of the manuscript. We also thank 2 anonymous reviewers for their helpful and detailed comments and corrections. This is UMCES contribution number 3602.

\section{LITERATURE CITED}

Andersen RA, Morton SL, Sexton JP (1997) Provasoli-Guillard National Center for Culture of Marine Phytoplankton. J Phycol Suppl to Vol 33 No. 6

Berges JA, Falkowski PG (1996) Cell-associated proteolytic enzymes from marine phytoplankton. J Phycol 32:566-574

Berges JA, Falkowski PG (1998) Physiological stress and cell death in marine phytoplankton: induction of proteases in response to nitrogen or light limitation. Limnol Oceanogr 43:129-135

Carlsson P, Granéli E (1998) Utilization of dissolved organic matter (DOM) by phytoplankton, including harmful species. In: Anderson DM, Cembella AD, Hallegraeff GM (eds) Physiological ecology of harmful algal blooms. Springer-Verlag, New York, p 509-524

Carlsson P, Edling H, Béchemin C (1998) Interactions between a marine dinoflagellate (Alexandrium catenella) and a bacterial community utilizing riverine humic substances. Aquat Microb Ecol 16:65-80

Caron DA, Goldman JC, Fenchel T (1990) Protozoan respiration and metabolism. In: Capriulo GM (ed) Ecology of marine protozoa. Oxford University Press, New York, p 307-322

Chróst RJ (1991) Environmental control of the synthesis and activity of aquatic microbial ectoenzymes. In Chróst RJ (ed) Microbial enzymes in aquatic environments. Springer-Verlag, New York, p 29-58

Crottereau C, Delmas D (1998) Exoproteolytic activity in an Atlantic pond (France): estimates of in situ activity. Aquat Microb Ecol 15:217-224

Dyhrman ST, Palenik BP (1997) The identification and purification of a cell-surface alkaline phosphatase from the dinoflagellate Prorocentrum minimum (Dinophyceae). J Phycol 33:602-612

Flynn KJ, Butler I (1986) Nitrogen sources for the growth of marine microalgae: role of dissolved free amino acids. Mar Ecol Prog Ser 34:281-304

Gifford DJ, Caron DA (2000) Sampling, preservation, enumeration and biomass of marine protozooplankton. In Harris RP, Wiebe PH, Lenz J, Skjoldal HR, Huntley M 
(eds) ICES zooplankton methodology manual. Academic Press, London, p 193-221

John EH, Flynn KJ (1999) Amino acid uptake by the toxic dinoflagellate Alexandrium fundyense. Mar Biol 133:11-19

Karner M, Ferrier-Pagès C, Rassoulzadegan F (1994) Phagotrophic nanoflagellates contribute to occurrence of $\alpha$-glucosidase and aminopepidase in marine environments. Mar Ecol Prog Ser 114:237-244

Loftus ME, Place AR, Seliger HH (1979) Inorganic carbon requirements of natural populations and laboratory cultures of some Chesapeake Bay phytoplankton. Estuaries 2:236-248

Long RA, Azam F (1996) Abundant protein-containing particles in the sea. Aquat Microb Ecol 10:213-221

Mahler HR, Cordes EH (1966) Biological chemistry. Harper \& Row Publishers, New York

Mannino A, Harvey HR (2000) Biochemical composition of particles and dissolved organic matter along an estuarine gradient: sources and implications for DOM reactivity. Limnol Oceanogr 45:775-788

Martinez J, Azam F (1993a) Aminopepitidase activity in marine chroococcoid Cyanobacteria. Appl Environ Microbiol 59:3701-3707

Martinez J, Azam F (1993b) Periplasmic aminopepitidase and alkaline phosphatase activities in a marine bacterium: implications for substrate processing in the sea. Mar Ecol Prog Ser 92:89-97

Martinez J, Smith DC, Steward GF, Azam F (1996) Variability in ectohydrolytic enzyme activities of pelagic marine bacteria and its significance for substrate processing in the sea. Aquat Microb Ecol 10:223-230

Mulholland MR, Glibert PM, Berg GM, Van Heukelem L, Pantoja S, Lee C (1998) Extracellular amino acid oxidation by microplankton: a cross-ecosystem comparison. Aquat Microb Ecol 15:141-152

Mulholland MR, Gobler CJ, Lee C (2002) Peptide hydrolysis, amino acid oxidation, and nitrogen uptake in communities seasonally dominated by Aureococcus anophagefferens. Limnol Oceanogr 47:1094-1108

Editorial responsibility: David Caron,

Los Angeles, California, USA
Palenik B, Morel FMM (1990a) Amino acid utilization by marine phytoplankton: A novel mechanism. Limnol Oceanogr 35:260-269

Palenik B, Morel FMM (1990b) Comparison of cell-surface Lamino oxidase from several marine phytoplankton. Mar Ecol Prog Ser 59:195-201

Porter KG, Feig YS (1980) The use of DAPI for identifying and counting aquatic microflora. Limnol Oceanogr 25:943-948

Rego JV, Billen G, Fontigny A, Somville M (1985) Free and attached proteolytic activity in water environments. Mar Ecol Prog Ser 21:245-249

Rosso AL, Azam F (1987) Proteolytic activity in coastal oceanic waters: depth distribution and relationship to bacterial populations. Mar Ecol Prog Ser 41:231-240

Sala MM, Güde H (1999) Role of protozoans on the microbial ectoenzymatic activity during the degradation of macrophytes. Aquat Microb Ecol 20:75-82

Sala MM, Karner M, Arin L, Marrasé C (2001) Measurement of ectoenzyme activities as an indication of inorganic nutrient imbalance in microbial communities. Aquat Microb Ecol 23:301-311

Sarath G, De La Motte RS, Wagner FW (1989) Protease assay methods. In Beynon RJ, Bond JS (eds) Proteolytic enzymes a practical approach. IRL Press, Oxford, p 25-55

Smayda TJ (1997) Harmful algal blooms: their ecophysiology and general relevance to phytoplankton blooms in the sea. Limnol Oceanogr 42:1137-1153

Somville M, Billen G (1983) A method for determining exoproteolytic activity in natural waters. Limnol Oceanogr 28: 190-193

Stoecker DK (1999) Mixotrophy among dinoflagellates. J Eukaryot Microbiol 46:397-401

Stoecker DK, Li A, Coats DW, Gustafson, DE Jr, Nannen MK (1997) Mixotrophy in the dinoflagellate Prorocentrum minimum. Mar Ecol Prog Ser 152:1-12

Tyler MA, Seliger HH (1978) Annual subsurface transport of a red tide dinoflagellate to its bloom area: water circulation patterns and organism distributions in the Chesapeake Bay. Limnol Oceanogr 23:227-246

Submitted: May 3, 2002; Accepted: July 26, 2002

Proofs received from author(s): November 18, 2002 